in pyriform sacs, appended on all sides to a comparatively small central part, from which the trunks of the nerves originate. The cerebrum and the other ganglia, like those of the great sympathetic nerve, present the appearance of small racemes; and if we wish to ascertain the origin of the nerves, it is in the midst of these masses of granules that we must seek it, notwithstanding the difficulty which this presents._Comptes Rendus, Nov. 20, 1865, p. 906.

\title{
On a new Kind of Illumination for Opaque Objects under High
} Powers. By Messrs. Smith, Beck, and Веск.

This method of illumination has been recently introduced by $\mathrm{Mr}$. Smith, of Kenyon College, U.S. * ; the best effect may, however, be obtained by the following exceedingly simple plan :-

Fig. 1.

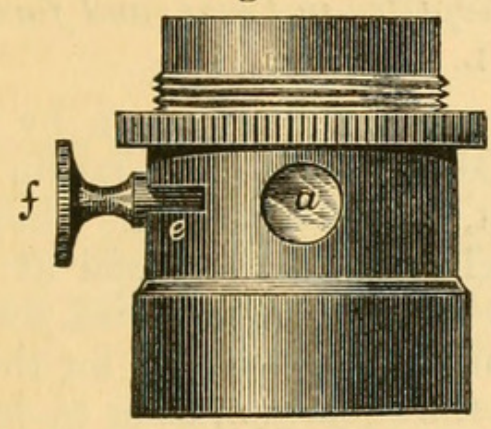

Fig. 3.

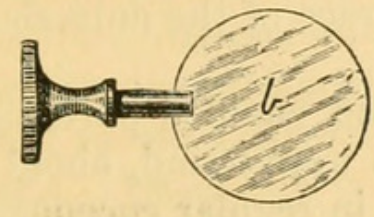

Fig. 2.

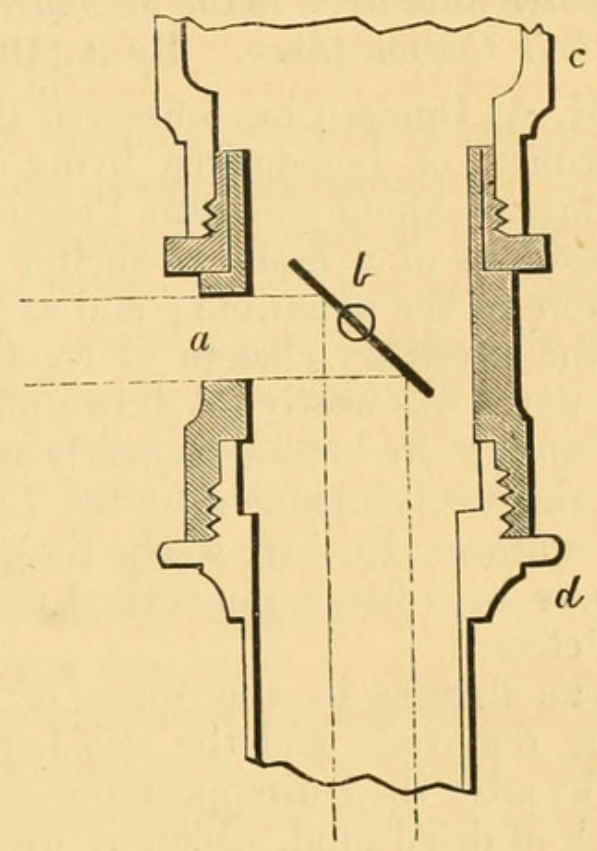

A piece of thin glass $(b)$, attached to a small brass milled head (fig. 3), fits into the side of an adapter (fig. 1); and when in position, as in figs. 1 and 2 , the light coming through a small circular aperture (a) may be reflected down and through the object-glass by the thin glass, which makes no obstruction to the rays of light passing upwards again from the object-glass to the eye-piece, nor even affects the definition to any perceptible degree.

The adapter (fig. l) is used, as shown in section (fig. 2), between the nose-piece $(c)$ and the object-glass $(d)$; it has a rotating fitting at the milled ring; and this movement, in combination with that of the small milled head to which the thin glass is attached, is sufficient for the nicest adjustment of the illumination. By means of a slot ( $e$, fig. 1 ) in the side of the adapter, the thin glass may be readily removed for the purpose of being wiped, as its perfect freedom from dust or smear is most essential.

* Silliman's Journal, September 1865. 
When using this piece of apparatus, the light should be opposite to the small aperture $(a)$, and in a position at right angles to the body of the microscope. When the lamp is used alone, an image of its flame will be seen upon the object; but the whole field of view may be illuminated, or unilateral light may be obtained, by placing a small condenser in different positions before the lamp.

Under this method of illumination, which is available with the highest powers, the appearances presented by objects are very remarkable, and they vary exceedingly according to the character and condition of the specimen. It is in all cases best to have the object uncovered. The subject is of great importance and interest, and requires thorough investigation; but this, from the moderate cost of the piece of apparatus $(10 s .6 d$.$) , is within the reach of every microscopist.$

Observations on some Lepidosirens (Protopterus annectens, Owen) which have lived in the Menagerie of Reptiles in Paris, and formed their Cocoon there. By A. DumériL.

M. A. Duméril has observed the formation of the cocoon by two specimens of Lepidosiren living in the Menagerie at the Jardin des Plantes. About the 20th February last, these two animals showed indications of a desire to shelter themselves in the soft soil at the bottom of the aquarium; and as previous specimens had died, owing to the necessary change of conditions not being realized for them, the water was nearly all drawn off from the aquarium, so as to leave the mud at its bottom as nearly as possible in the same condition as the rice-fields inhabited by the Lepidosiren at the approach of the dry season. In three weeks the ground gradually hardened, forming a mass with fissures in several parts; no trace of the animals was to be detected.

The fissures in the mass of dried mud enabled portions of it to be removed; and the two Lepidosirens were found, about eleven weeks after their disappearance, enveloped in regular cocoons. The block of dried mud, which is preserved in the museum, exhibits a cavity moulded upon the cocoon, with the walls perfectly smooth and lined with a strongly adherent portion of the cocoon.

This cocoon is produced by a mucous secretion. Its brown colour might lead to the supposition that it is formed of dried leaves ; but when examined by Professor Decaisne, it presented no trace of vegetable structure; and when burnt, it diffused the characteristic odour of animal substances.

The Lepidosirens, when desirous of burying themselves, emit an abundant mucosity from the surface of the body. This coats and agglutinates the portions of the soil which they traverse, so that the walls of the subterranean canal made by each animal and remaining open after desiccation are smooth and appear polished; then when the animal stops, this exudation acquires the consistency of a membranous envelope. The Lepidosirens when examined by $\mathbf{M}$. Duméril were still alive, as was proved by their slight movements when touched; they have since died.-Comptes Rendus, January 8, 1866, p. 97. 


\section{$2 \mathrm{BHL}$ Biodiversity Heritage Library}

Smith, H. L. and Beck, Richard. 1866. "On a new kind of illumination for opaque objects under high powers." The Annals and magazine of natural history; zoology, botany, and geology 17, 159-160.

View This Item Online: https://www.biodiversitylibrary.org/item/54464

Permalink: https://www.biodiversitylibrary.org/partpdf/53713

\section{Holding Institution}

Smithsonian Libraries

\section{Sponsored by}

Smithsonian

\section{Copyright \& Reuse}

Copyright Status: Public domain. The BHL considers that this work is no longer under copyright protection.

This document was created from content at the Biodiversity Heritage Library, the world's largest open access digital library for biodiversity literature and archives. Visit BHL at https://www.biodiversitylibrary.org. 